species of Alestes, Synodontis afro-fischeri and Marcusenius grahami eat mostly insects, whereas Barbus altianalis and Synodontis victoriae get most of their sustenance from snails. Other appendixes contain shorter notes on a variety of topies, including the growth of Tilapia zillii in a dam and some preliminary observations on the control by fish of snails and mosquitoes in dams.

The director, Mr. R. S. A. Beauchamp, who has recently relinquished the post he has held with distinction since he opened the Laboratory in 1948, can look back on a considerable achievement. Not only have he and his colleagues laid a firm foundation of knowledge of the hydrography, chemistry and biology of at least the parts of Lake Victoria within the reach of the Laboratory, but they have also made significant contributions, briefly described in the reports of which this is the latest, to our understanding of the factors which control the productivity of tropical waters. Moreover, the Laboratory itself now has a world-wide reputation and attracts visitors from many countries.

H. C. GILson

\title{
U.S. MATERIALS RESEARCH AND DEVELOPMENT FOR NATIONAL SECURITY
}

\begin{abstract}
A SPECIAL Committee on Scope and Conduct of Materials Research was appointed by $\mathrm{Dr}$. D. W. Bronk, president of the National Academy of Sciences, to review the materials research noeds of the United States with regard to national defence and the public welfare generally; to appraise the adequacy of the present research programmes to meet those needs; to consider the resources available ; and to make recommendations. A report now issued under the title "More Effective Organization and Administration of Materials Research and Development for National Security" deals with the scope of materials research from the point of view of the overall adequacy of the present effort, but leaves for continuing review by the Materials Advisory Board of the National Academy of Sciences-National Research Council the question of scope in regard to the technical content of the programme*. The question of scope in regard to the scientific content will be dealt with in a forthcoming report of the Academy-Research Council's Committee on Perspectives in Materials Research.

The Committee found that important national security programmes, particularly in defence, nuclear energy and space-research are impeded by the inadequacy of the properties of most of the materials now available to withstand the severe temperature,

- Tational Academy of Sciences-National Research Council. Publication No. 718: More Effective Organization and Administration of Materials Research and Development for National Security. (A Report to D. W. Bronk, President, National Academy of Sciences, by the Committee on Scope and Conduct of Materials Research.) Pp. ix +30 . (Washington, D.C.: National
\end{abstract}

pressure, radiation, corrosion and stress conditions involved and give high performance. The Committee recommends accordingly that the Government accord high priority in national security plans and programmes to the development of new and improved materials and that the relevant programmes of the agencies and departments be strengthened. Tho Committee recognizes that there is no simple solution, but that every level of activity needs significant strengthening. To this end it recommends greater centralization of responsibility, more support for, and more effective co-ordination of Governmentsponsored materials research and development programmes; Government incentives to encourage rosearch and development on new and improved materials; and steps to assure adequate supplies in the United States of every chemical element or material to support full production and use of new and improved materials. It also recommends improvement in the dissemination of research information and strengthening the universities in their dual role of training scientists and engineers and pursuing research. In regard to the last, the Committee endorses a recently announced programme of Government-sponsored interdisciplinary materials laboratories at several institutions of higher learning, while as regards the dissemination of information it envisages the encouragement and acceleration of publication and removal of secrecy restrictions as well as the greater support of research designed to encourage rapid exchange of technical and scientific information, including expansion and acceleration of the Critical Tables project.

\section{EDUCATION AND INDUSTRY}

$\mathrm{B}$ RITISH industry has traditionally been badly served by the universities and by the majority of schools. Until quite recently, they have encouraged very few of the ablest young people to think in terms of an industrial career.

The prejudice was not all on one side. The typical industrialist of not so long ago, while he was ready enough to concede the importance of craft training, and even of technical education, conceived rather narrowly, held that industry had certainly no responsibility for any but quite specialized courses, and that no useful purpose would be served by recruiting men on a basis of intellectual quality rather than skill.
Prof. D. G. Christopherson, in a recent issue of the Esso Magazine (Spring, 1960), suggests that, although these attitudes are changing, it is the attitude of industry which has changed most quickly and most completely in our time. Before the War, most professors of engineering spent their time resisting pressure from industry in the direction of making courses more specifically technical, so that the graduate would be better able to do a particular job immediately on joining the firm. To-day, the influence of industry is in the opposite direction. Professors of engineering are urged to keep courses general, to resist undue specialization, at least until 
postgraduate-level, and to include as much material as possible of a completely non-technological character. Although employers are still interested in the professional side of what the university does, most place the greatest emphasis on intellectual quality rather than on technical expertise.

There are a number of reasons for this. In the first place, as the rate of scientific and technological progress quickened, the need for people to be adaptable, quick to learn, and capable of covering a wide field has increased. It is no good giving a man a complete specialized training if what he has specialized in is obsolete before he has reached the age of thirty.

Secondly, a large proportion of university graduates do not in fact do the job for which officially they were trained for more than a quite small proportion of their careers. Finally, as industrial concerns get larger and the place of industry in the national life increases in importance, the scope of the decisions to be taken by industry become even wider, reaching far beyond the boundaries of straightforward technical questions.

There is a fruitful field for active collaboration between the universities and industry. Many students already go to industry for vacation courses. It should be possible to relate what is done in industry much more closely to the academic side than had been done in the past. It might be possible for undergraduates and even more for postgraduates to do part of their 'course work' as an investigation of some industrial problem 'in the field'. The 'sandwich courses' in the colleges of advanced technology may prove to be the pioneers in this field.

But, no matter how good an understanding is achieved between education and industry, and no matter how courses are adjusted to meet contemporary needs, education cannot be thought of as a process which finishes in the early twenties. Some sabbatical period is as essential for men in industry as in the universities. Specialized postgraduate courses on technical subjects for people released from industry are becoming commoner and better supported. The universities and particularly the faculties of science and technology must be prepared to organize more of these courses.

Advanced technical work is not the most important purpose for which industry requires its own 'sabbatical years'. There is a stage at which intellectual renewal is particularly valuable, the stage when a man emerges from a relatively specialized department and begins to take managerial responsibility over a wider field; by that time, he has enough experience to be able to appreciate what the problems of management actually are, but usually scarcely any systematio knowledge of how they have been mastered.

Education in management in Great Britain lags a long way behind that in the United States; this is a matter to which the universities must give much more serious attention. By far the greatest difficulty is the recruiting of suitable staff. Management is essentially a practical subject, and the man who is good at it wants to practise and not to instruct.

A managerial or business school recruiting 'students' from a wide variety of industries would be better than one run by one undertaking, no matter how large; this end can perhaps be most directly achieved by co-operation between the great companies in founding their own institutions rather than by working through the existing university structure.

\section{TRAINING IN RADIOLOGICAL HEALTH AND SAFETY}

$\mathrm{O}$ $\mathrm{N}$ the night of October 10,1957 , the core of No. 1 reactor at the Atomic Energy Authority works at Windscale became seriously over-heated and as a consequence a fairly large amount of radioactive material escaped through the reactor stack and was deposited thinly over many square miles of northwest England. Once the alarm was given, the Health and Safety Services of the Authority went into action on their first major emergency test. Fortunately no significant harm was done to the populations of the surrounding areas, although the affair naturally received widespread publicity.

By now the 'Windscale incident' has almost passed into history, but it is interesting to find unexpected repercussions almost three years later. Following the accident, the Prime Minister set up a Committee under Sir Alexander Fleck to report, among other things, on the organization for control of health and safety in the United Kingdom Atomic Energy Authority. The report of this Committee directed attention to the serious shortage of trained radiological health and safety specialists and called for comprehensive schemes of instruction in this field as a "matter of urgent national importance". The Fleck Committee firmly placed the onus of leading the build-up of a national supply of specialists on the Atomic Energy Authority. In view of this, the Authority set up a further Committee under Sir Douglas Veale to consider what steps should be taken to provide a staff concerned with health and safety for the Authority, and for the nation as a whole, including the establishment of a national training centre*.

Although now a matter of extensive public concern, radiological health and safety are by no means a new problem. The hazards to man of ionizing radiations have been known since the early years of the century, and the distressing experiences of the early radiological workers have kept the matter well to the fore in the minds of their successors. In 1921 the first concerted effort to deal with the problem came with the publication of the first Recommendations of the British Committee for Radiological Protection. This was quickly followed by other national recommen. dations and by the Recommendations of the Inter. national Commission; the latter, revised from time to time, still form the basis of world-wide radiological protection measures. Until 1945, radiological safety was a matter of concern limited almost entirely to medical radiologists and a handful of physicists attached to hospitals and medical schools. The development of nuclear reactors and weapons changed. the whole picture. Production and uses of ionizing radiations have increased enormously, the number of persons occupationally exposed has increased correspondingly, and we are now faced with the position * Report of the Committec on Training in Health and Safety to
the Authority Committee on Health and Safety, United Kingdom Atomic Energy Authority, February 1960. Pp. vi +95. (London: 